\title{
EDITORIAL
}

\section{El desierto y su dinamismo}

\author{
The dynamism of the desert
}

\section{Dr. Benjamín José Dávila Flores \\ Facultad de Ciencias Biológicas \\ Universidad Nacional de San Agustín \\ Arequipa, Perú}

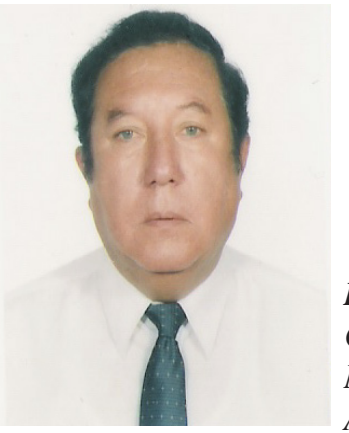

Ph D. Benjamín José Dávila Flores

College of Biological Sciences

National University of Saint Augustine

Arequipa, Peru
El desierto, siendo un bioma o paisaje bioclimático o área biótica, tiene un dinamismo característico. Allí también se presentan los tres pilares fundamentales ecológicos: interdependencia, limitación y complejidad. Por ello, cuando llamamos al desierto un conjunto de ecosistemas "simples o menos complejos" quizá estamos lejos de expresar las interrelaciones y procesos que se producen en esta zona.

Aunque existen limitaciones en el desierto como ocurre en todo ecosistema o conjunto de ecosistemas (son limitaciones de diversos tipos):

Se desarrolla en regiones con menos de $225 \mathrm{~mm}$ de lluvia anual.

Por lo tanto hay escasez de agua y las lluvias son muy irregulares.

La evaporación es muy alta.

Falta de vegetación y escasez de suelo, que es arrastrado por la erosión eólica, etc.

\section{Pero el desierto es un ecosistema o conjunto} de ecosistemas (o bioma) que vive la paradoja de tener como frontera al mar u oceáno.

El océano abierto y los desiertos tienen la productividad primaria denominada "baja", inferior a 0,5 gramos por metro cuadrado y día.
Deserts are a biome, bioclimatic landscape or biotic area with a characteristic dynamism, including the fundamental ecological pillars: interdependence, limitation and complexity. Thus if we call a desert a set of "simple or less complex" ecosystems, we do not take into account the interrelations and processes which occur there.

Although there are limitations in all ecosystems or sets of ecosystems, deserts have particular limitations, including:

They develop in areas with less than 225 mm annual precipitation.

Rain is very irregular, thus there is a scarcity of water.

Evaporation is very high.

There is a lack of vegetation and a scarcity of soil, which is blown away by wind erosion, etc.

But a desert is an ecosystem or set of ecosystems (or biome) that has the paradox of having a sea or ocean as a frontier.

The open ocean and deserts have low primary productivity, less than $0.5 \mathrm{~g} \mathrm{~m}^{-3}$ day'. However, there are very interesting mechanisms and processes in deserts: the scarce vegetation assures the existing 
Pero en el desierto existen mecanismos y procesos muy interesantes: la vegetación escaza se asegura los nutrientes existentes en el suelo, las especies vegetales sincronizan sus ciclos de vida con las lluvias, y cuando sus semillas germinan y dan flores allí están los insectos que tienen ciclos adaptados a las de las plantas que ayudan a polinizar. Hay especies vegetales que tienen largas raíces que pasan periodos de latencia hasta que exista la humedad adecuada. También hay especies suculentas que acumulan agua, poseen espinas para contrarresta la herbivoría y la rigidez de sus formas hace frente a la desecación del viento, tienen cutículas delgadas, estomas escondidos y una baja relación superficievolumen, que les permite reducir la pérdida de agua. Otras especies sobreviven gracias a los grandes bulbos o tubérculos con agua y nutrientes que mantienen por debajo del suelo, sin dejar de mencionar la microflora que también permanece latente hasta que haya las condiciones adecuadas.

Reptiles e insectos son capaces de sobrevivir a las condiciones del desierto, porque sus cuerpos son prácticamente impermeables y sus excreciones son secas. Algunos mamíferos están adaptados para superar la escasez de agua por medio de excreciones de orina concentradas y han evolucionado para mantenerse frescos y disminuir notablemente el consumo de líquido. Algunos incluso, pueden sobrevivir sin haber tomado agua.

No hay que deteriorar el desierto ya que también conduce a una pérdida de diversidad biológica y del patrimonio cultural, los grupos humanos siempre han estado ligados a él. Más bien hay que cultivar en el desierto, aumentar la productividad que existe en forma natural allí, para combatir el hambre en el mundo, pero cuidando de hacer frente a problemas como agotamiento de las fuentes de agua y la salinización. nutrients in the soil; the plant species synchronize their life cycles with the rains; when the annual species flower, the insects, which have adapted their cycles to the plants, are there to feed and pollinate; there are plant species with long roots that go through periods of latency until there is sufficient humidity; there are succulent species that accumulate water, have spines that discourage herbivory and rigid structures that resist desiccation due to wind, have thin cuticles, hidden stomata and a low surfacevolume ratio which reduces water loss; other species survive dry periods in the soil as large bulbs or tubercula with water and nutrients; and microflora that also remains latent until adequate growing conditions occur.

Reptiles and insects can survive desert conditions, because their bodies are nearly impermeable and they excrete little. Some mammals have adapted to survive the lack of water by concentrated urine excretion, and have evolved mechanisms to maintain themselves cool and decrease water consumption notably; there are a few that can survive without ever drinking water.

Deserts should not be deteriorated, since this would cause a loss of biological diversity, and also a loss of cultural heritage, since human groups have always been linked to deserts. It would be better to cultivate deserts and increase the natural productivity that exists in them to combat hunger in the world, with adequate planning in order to avoid depleting water sources or making the soil saline. 